\title{
ANALISIS PARAMETER FISIKA DAN KESADAHAN AIR PDAM WAINITU AMBON
}

\author{
A. N. Latupeirissa ${ }^{1^{*}}$, J. B. Manuhutu ${ }^{2}$ \\ ${ }^{1}$ Departement of Physic-FKIP, Pattimura University Ambon \\ ${ }^{2}$ Departement of Chemistry-FKIP, Pattimura University Ambon \\ *astridnelania@gmail.com
}

\begin{abstract}
A research has been carried out on the analysis of physical parameters and water hardness of PDAM Wainitu Ambon. The purpose of this study was to determine the physical parameters as well as its $\mathrm{pH}$ and hardness of Wainitu PDAM in its water sources, water treatment plants, and the customer faucets including: odor, taste, color, temperature and total disolved solids (TDS), and $\mathrm{pH}$ and hardness. The methods used were observation in the field at the time of sampling and measurement and analysis in the laboratory. The results of the study indicate that the physical parameters of the water such as odor, taste, color, total disolved solids (TDS), the pH, and hardness have met the drinking water quality standards according to the Minister of Health Regulation Number. 492 / Menkes / per / IV / 2010.
\end{abstract}

Keywords: PDAM water, hardness, physical parameters.

\section{ABSTRAK}

Telah dilakukuan penelitian tentang analisis parameter fisika dan kesadahan air PDAM Wainitu Ambon. Tujuan penelitian ini adalah Untuk menentukan uji parameter fisika serta $\mathrm{pH}$ dan kesadahan pada sumber air PDAM Wainitu, air pada instalasi pengolahan air PDAM Wainitu dan air pada kran pelanggan PDAM Wainitu meliputi: bau, rasa, warna, suhu dan jumlah zat padat terlarut (TDS), serta pH dan kesadahan. Metode yang digunakan adalah metode observasi di lapangan pada saat pengambilan sampel dan pengukuran dan analisis di laboratorium. Adapaun hasi penelitian menunjukkan bahwa parameter fisika air yaitu: bau, rasa, warna, jumlah zat padat terlarut (TDS), serta $\mathrm{pH}$ dan kesadahan sudah memenuhi standar kualitas air minum menurut Peraturan Menteri Kesehatan Nomor. 492/Menkes/per /IV/2010.

Kata kunci: air PDAM, kesadahan, parameter fisika.

\section{PENDAHULUAN}

Slamet (2007) menyatakan bahwa syarat kualitas meliputi parameter fisik, kimia dan mikrobiologis yang memenuhi syarat kesehatan. Menurut Peraturan Menteri Kesehatan Nomor. 492/Menkes/per/IV/2010 Tanggal 19 April 2010 tentang syarat-syarat dan pengawasan kulaitas air. Dari segi parameter fisika dan kimia, air yang baik adalah air yang tidak berasa, berbau dan berwarna, serta yang tidak berbahaya bagi kesehatan. $\mathrm{pH}$ air sebaiknya tidak asam dan tidak basa (netral) untuk mencegah terjadinya pelarutan logam berat dan korosi jaringan distribusi air. $\mathrm{pH}$ yang dianjurkan air bersih adalah 6,5-8,5. Air yang bersih biasanya tidak estetis juga tidak akan disukai oleh masyarakat. Bau air akan memberi petunjuk akan kualitas air. Rasa, air yang bersih biasanya tidak memberikan rasa atau tawar. Air yang tidak tawar menujukkan kehadiran berbagai zat yang dapat membahayakan kesehatan (Ghufran, 2007). 
Warna, air sebaiknya tidak berwarna untuk alasan estetis dan untuk mencegah keracunan dari berbagai zat kimia maupun mikroorganisme yang berwarna. Untuk standar air bersih diharapkan zat warna 50 TCU dan untuk standar air minum maksimum 15 TCU kandungan zat warna. Untuk kekeruhan, air dikatakan keruh apabila, air tersebut mengandung begitu banyak partikel bahan yang tersuspensi sehingga memberikan warna atau rupa yang berlumpur dan kotor. Tingkat kekeruhan air dapat diketahui melalui pemeriksaan laboratorium dengan menggunakan Turbidimeter. Untuk standar air bersih kekeruhan yang diperbolehkan maksimum 25 NTU dan 5 NTU untuk standar air minum. Suhu, suhu air sebaiknya 10-25 OC (sejuk) agar tidak terjadi pelarutan zat kimia yang ada pada saluran atau pipa yang dapat membahayakan kesehatan. Jumlah zat padat Terlarut (TDS), biasanya terdiri dari zat organik, garam anorganik, dan gas terlarut. Bila TDS bertambah maka kesadahan akan naik pula. Selanjutnya, efek TDS ataupun kesadahan terhadap kesehatan tergantung pada zat kimia penyebab masalah tersebut (Tresna, 2009).

Defenisi air minum di dalam keputusan Menteri Kesehatan Nomor Nomor. 492/Menkes/per/IV/2010 Tanggal 19 April 2010 tentang syarat-syarat pengawasan kualitas air minum. Air minum adalah air yang melalui proses pengolahan atau tanpa proses pengolahan yang memenuhi syarat ketentuan yang berlaku, dan dapat langsung diminum (Permenkes RI, 2010). Untuk memenuhi kebutuhan air sehari-hari yang semakin meningkat, keberadaan air bersih sangat dibutuhkan oleh masyarakat untuk memenuhi kebutuhan sehari-hari. Keberadaan PDAM, dapat membantu masyarakat. PDAM adalah Perusahaan air minum yang dikelola oleh pemerintah yang bertujuan untuk memenuhi kebutuhan masyarakat secara perorangan untuk kebutuhan sehari-hari.

Pada penelitian ini akan dilakukan uji parameter fisika dan $\mathrm{pH}$ serta kesadahan pada sumber air PDAM Wainitu, air pada instalasi pengolahan air PDAM Wainitu dan air pada kran penganggan PDAM Wainitu meliputi: bau, rasa, warna, jumlah zat padat terlarut (TDS), suhu, pH dan kesadahan. Pada penelitian selanjutnya akan diuji kualitas air minum PDAM Wainitu secara keseluruhan parameter kimia dan biologi.

\section{METODE PENELITIAN}

\section{Tahapan-Tahapan Penelitian}

Metode penelitian yang digunakan yaitu pengambilan sampel di lapangan dan diuji di laboratorium. Penelitian akan dilakukan melalui tahapan sebagai berikut:

\section{Bahan dan Alat Penelitian}

\section{Bahan}

Bahan yang digunakan dalam penelitian ini adalah

1. Sampel air PDAM Wainitu Nusaniwe

2. Amonium hidroksida ( $\mathrm{NH} 4 \mathrm{OH})$, p.a (E.Merck)

3. Garam magnesium EDTA p.a (E. Merck)

4. Erichome Black T (EBT) p.a (E.Merck)

5. Asam klorida $(\mathrm{HCl})$ p.a (E.Merck)

6. Larutan buffer kalsium karbonat (CaCO3) p.a (E.Merck)

7. Isopropil alkohol p.a (E.Merck)

8. Hidroksiamin hidroklorida p.a (E.Merck)

\section{Alat}

Alat-alat yang digunakan dalam penelitian antara lain

1. Peralatan gelas laboratorium (Pyrex),

2. Botol sampel 


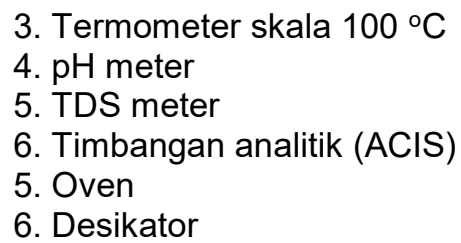

Prosedur Kerja

\section{Pengambilan Sampel}

Pengambilan sampel berupa tiga titik lokasi yaitu sumber air yaitu air Wainitu Ambon, dilakukan di titik hisap pipa PDAM dengan dasar penelitian hanya fokus terhadap air yang digunakan untuk PDAM, air yang diambil di instalasi pengolahan air PDAM dilakukan di mana air dari sumber air ditampung dan air pada kran pelanggan PDAM dengan jarak rumah yang berbeda

\section{Preparasi Sampel (Uji Laboratorium)}

A. Parameter-Parameter yang diteliti:

1. Pemeriksaan bau, rasa dan warna

Secara fisik, sampel air minum PDAM pada keempat titik lokasi dapat dibaui, dirasa dan dilihat warna sampel tersebut secara langsung.

2. Penentuan Suhu $\left({ }^{\circ} \mathrm{C}\right)$

Sampel air minum PDAM dituangkan ke dalam botol sampel, kemudian termometer skala $100{ }^{\circ} \mathrm{C}$ dicelupkan ke dalam sampel air. Setelah 2-3 menit, dibaca skala termometer dan dicatat temperaturnya.

\section{Penentuan TDS}

Sampel air minum PDAM yang diambil pada keempat lokasi dimasukkan dalam botol sampel dan dibawa ke laboratorium. Kemudian sampel yang ada dalam botol sampel dimasukan kedalam gelas kimia. Celupkan bagian TDS meter yang memiliki bagian besi ke sampel yang akan diukur. Setelah TDS meter dicelupkan ke sampel, TDS meter secara otomatis akan mulai menghitung kandungan zat padat terlarut pada sampel. Tunggu kurang lebih 1 menit hingga angka pada TDS meter tidak berubah-ubah. Angka pada TDS meter menunjukkan banyaknya kandungan zat padat terlarut yang ada pada sampel, dan dicatat hasilnya.

4. Penentuan derajat keasaman $(\mathrm{pH})$

Sampel air minum PDAM yang diambil pada keempat lokasi dimasukkan dalam botol sampel dan dibawa ke laboratorium. Kemudian sampel yang ada dalam botol sampel dimasukkan ke dalam gelas kimia. Nyalakan dengan menekan tombol on pada $\mathrm{pH}$ meter, kemudian $\mathrm{pH}$ meter dicelupkan ke dalam sampel. Saat $\mathrm{pH}$ meter dicelupkan ke dalam air, skala angka akan bergerak acak, tunggu hingga angka tersebut tidak berubah-ubah, dan catat hasilnya.

\section{HASIL PENELITIAN}

\section{Kondisi Tempat Pengambilan Sampel}

PDAM merupakan perusahaan daerah sebagai sarana penyedia air bersih yang diawasi dan dimonitor oleh aparat- aparat eksekutif maupun legislatif daerah. Sumber air PDAM Wainitu Ambon berasal dari air permukaan tanah yang telah ditampung dalam bak pelanggan. Kemudian air tersebut dialirkan dalam instalasi untuk disalurkan ke masyarakat sebagai pelanggan. Dalam penelitian ini ada empat lokasi pengambilan sampel yaitu: air pada sumber PDAM Wainitu Ambon, air yang diambil di instalasi pengolahan air PDAM dan pada kran pelanggan PDAM dengan jarak rumah yang berbeda (pelanggan yang dekat dari sumber air PDAM \pm 20 meter, dan pelanggan yang jauh $\pm 1 \mathrm{Km}$. Air PDAM Wainitu Ambon digunakan dalam kebutuhan sehari-hari oleh masyarakat sekitarnya, baik 
untuk diminum atau untuk kebutuhan lainnya. Defenisi air minum di dalam keputusan Mentri Kesehatan Nomor. 492/Menkes/per/IV/2010 Tanggal 19 April 2010 tentang syarat-syarat pengawasan kualitas air minum. Air minum adalah air yang melalui proses pengolahan atau tanpa proses pengolahan yang memenuhi syarat ketentuan yang berlaku, dan dapat langsung diminum (Permenkes RI, 2010).

\section{Penentuan Parameter Air PDAM Wainitu Ambon}

Kualitas air secara umum menunjukkan mutu atau kondisi air yang dikaitkan dengan suatu kegiatan atau keperluan tertentu, sedangkan kuantitas menyangkut jumlah air yang dibutuhkan manusia dalam kegiatan tertentu. Air adalah materi esensial didalam kehidupan, tidak ada satupun makhluk hidup di dunia ini yang tidak membutuhkan air. Sebagian besar tubuh manusia itu sendiri terdiri dari air. Tubuh manusia rata-rata mengandung air sebanyak $90 \%$ dari berat badannya. Tubuh orang dewasa, sekitar $55-60 \%$, berat badan terdiri dari air, untuk anak-anak sekitar $65 \%$ dan untuk bayi sekitar $80 \%$ (Gusril, 2016)

Air bersih dibutuhkan dalam pemenuhan kebutuhan manusia untuk melakukan segala kegiatan mereka. Sehingga perlu diketahui bagaimana air dikatakan bersih dari segi kualitas dan bisa digunakan dalam jumlah yang memadai dalam kegiatan sehari-hari manusia. Ditinjau dari segi kualitas, ada beberapa persyaratan yang harus dipenuhi, diantaranya kualitas fisik yang terdiri atas bau, rasa, warna, jumlah zat terlarut dan kualitas kimia yang terdiri atas $\mathrm{pH}$, kesadahan, serta kualitas biologi dimana air terbebas dari mikroorganisme penyebab penyakit. Agar kelangsungan hidup manusia dapat berjalan lancar, air bersih juga harus tersedia dalam jumlah yang memadai sesuai dengan aktifitas manusia pada tempat tertentu dan kurun waktu tertentu.

Air sebagai materi esensial dalam kehidupan tampak dari kebutuhan terhadap air untuk keperluan sehari-hari di lingkungan rumah tangga ternyata berbeda-beda di setiap tempat, setiap tingkatan kehidupan atau setiap bangsa dan negara. Semakin tinggi taraf kehidupan seseorang semakin meningkat pula kebutuhan manusia akan air. Air merupakan faktor penting dalam pemenuhan kebutuhan vital bagi mahluk hidup diantaranya sebagai air minum atau keperluan rumah tangga lainnya. Air yang digunakan harus bebas dari kuman penyakit dan tidak mengandung bahan beracun. Sumber air minum yang memenuhi syarat sebagai air baku air minum jumlahnya makin lama makin berkurang sebagai akibat ulah manusia sendiri baik sengaja maupun tidak disengaja (Suriawiria,1996).

Akan tetapi air yang dipergunakan tidak selalu sesuai dengan syarat kesehatan, karena sering ditemui air tersebut mengandung bibit ataupun zat-zat tertentu yang dapat menimbulkan penyakit yang justru membahayakan kelangsungan hidup manusia. Kebutuhan air minum bagi manusia harus terpenuhi baik secara kualitas maupun kuantitasnya agar manusia mampu hidup dan menjalankan segala kegiatan dalam kehidupannya.

Ditinjau dari segi kualitas (mutu) air secara langsung atau tidak langsung pencemaran akan berpengaruh terhadap kualitas air. Sesuai dengan dasar pertimbangan penetapan kualitas air minum, usaha pengelolaan terhadap air yang digunakan oleh manusia sebagai air minum berpedoman pada standar kualitas air terutama dalam penilaian terhadap produk air minum yang dihasilkannya, maupun dalam merencanakan sistem dan proses yang akan dilakukan terhadap sumber daya air. Dan Berdasarkan Peraturan Menteri Kesehatan Nomor 492/Menkes/per/IV/2010 Tanggal 19 April 2010 tentang syarat-syarat dan pengawasan kualitas air jernih, tidak berwarna, tidak berasa, tidak berbau, tidak mengandung kuman pantogen, tidak mengandung makluk lain yang membahayakan kesehatan manusia, tidak mengandung zat kimia dan memenuhi standar mutu (Sutrisno, 2006).

Parameter kualitas air PDAM Ambon sebagai sampel penelitian yang digunakan untuk kebutuhan masyarakat sehari-hari diperlihatkan pada Tabel 2 sebagai berikut: 
Tabel 1. Parameter air PDAM Wainitu Ambon

\begin{tabular}{|c|c|c|c|c|c|}
\hline \multirow{2}{*}{ Parameter } & \multicolumn{4}{|c|}{ Lokasi Pengambilan Sampel } & \multirow[t]{2}{*}{ Keterangan } \\
\hline & L4 & L2 & L3 & L4 & \\
\hline Bau & Tidak berbau & Tidak berbau & Tidak berbau & Tidak berbau & Memenuhi Standar \\
\hline Rasa & Tidak berasa & Tidak berasa & Tidak berasa & Tidak berasa & Memenuhi Standar \\
\hline Warna & Tidak Berwarna & Tidak Berwarna & Tidak Berwarna & Tidak Berwarna & Memenuhi Standar \\
\hline Suhu (C) & 25 & 25 & 27 & 29 & Memenuhi Standar \\
\hline $\begin{array}{l}\text { TDS } \\
(\mathrm{mg} / \mathrm{L})\end{array}$ & 201 & 185 & 183 & 183 & Memenuhi Standar \\
\hline $\mathrm{pH}$ & 8 & 8 & 8,3 & 8,2 & Memenuhi Standar \\
\hline $\begin{array}{l}\text { Kesadahan } \\
(\mathrm{mg} / \mathrm{L})\end{array}$ & 98,09 & 90,82 & 89,09 & 84,07 & Memenuhi Standar \\
\hline
\end{tabular}

\section{Bau}

Bau air PDAM pada keempat lokasi penelitian tidak berbau, hal ini menunjukkan air PDAM Ambon yang tidak berbau memenuhi syarat untuk minum Air yang baik memiliki ciri tidak berbau bila dicium dari jauh maupun dari dekat. Air yang berbau busuk mengandung bahan organik yang sedang mengalami dekomposisi (penguraian) oleh mikroorganisme air. Berdasarkan panduan dari Badan Kesehatan Dunia (WHO) dalam buku Pengolahan dan standar kualitas air. Air yang layak untuk dikonsumsi adalah air yang tidak berbau. Sedangkan menurut penelitian yang didapat sampel air PDAM juga tidak berbau. Jadi sesuai dengan standar yang ditetapkan oleh Menteri Kesehatan No.492/Menkes/per/IV/2010 Tanggal 19 April 2010. Mekanisme kerja untuk meneliti bau air dilakukan di lokasi pengambilan sampel. Dengan cara pengambilan air menggunakan botol lalu diteliti dengan alat indra (hidung).

\section{Rasa}

Rasa air PDAM pada keempat lokasi penelitian tidak berasa. Air yang tidak berasa memenuhi standar baku air menurut Menkes Kesehatan. Secara fisika, air bisa dirasakan oleh lidah. Air yang terasa asam, manis, pahit atau asin menunjukkan air tersebut tidak baik. Rasa asin disebabkan adanya garam-garam tertentu yang larut dalam air, sedangkan rasa asam diakibatkan adanya asam organik maupun asam anorganik. Hasil analisis secara langsung terhadap sampel air PDAM pada daerah penelitian yaitu tidak berasa. Mekanisme kerja untuk meneliti rasa air dilakukan dilapangan. Sedangkan standar yang ditetapkan oleh Menteri Kesehatan bahwa dalam air minum sebaiknya tidak berasa. Jadi sudah sesuai dengan standar yang ditetapkan oleh Menteri Kesehatan No. 492/Menkes/per/IV/2010 Tanggal 19 April 2010. Dengan cara pengambilan air dari lokasi penelitian menggunakan botol lalu diteliti dengan alat indra (lidah).

\section{Warna}

Warna air PDAM pada keempat lokasi penelitian menunjukkan air tidak berwarna (jernih) sehingga dapat memenuhi syarat untuk air minum. Air yang tidak berwarna memenuhi syarat untuk air minum. Air untuk keperluan rumah tangga harus jernih. Air yang berwarna berarti mengandung bahan-bahan lain yang berbahaya bagi kesehatan. Jadi sesuai dengan standar yang ditetapkan oleh Menteri Kesehatan bahwa dalam air minum sebaiknya tidak berwarna. Warna air dapat ditimbulkan oleh hasil dari kontak antara air dengan organisme yang mengalami pembusukan. Partikel-partikel lumpur yang 
terinfiltrasi ke dalam pipa air PDAM. Dengan cara pengambilan air dari lokasi penelitian pusat air PDAM menggunakan botol lalu diteliti dengan alat indra (mata).

\section{Suhu}

Suhu pada air yang diperbolehkan oleh Peraturan Menkes 2010 yaitu $\pm 3{ }^{\circ} \mathrm{C}$. Sesuai hasil penelitain menunjukkan bahwa sampel air PDAM suhunya memenuhi syarat kualitas air bersih yaitu berkisar antara $25-29^{\circ} \mathrm{C}$. Cara pengukuran suhu yaitu masukkan termometer ke dalam sampel air, tunggu 23 menit kemudian baca skala atau angka yang tertera pada termometer. Suhu air sebaiknya sejuk atau tidak panas terutama agar tidak terjadi pelarutan zat kimia yang ada pada saluran/pipa, yang dapat membahayakan kesehatan dan menghambat pertumbuhan mikroorganisme.

\section{TDS}

TDS (Total Disolved Solid) atau jumlah zat padat terlarut pada air yang diperbolehkan oleh Menkes Kesehatan 2010 yaitu maksimum 500 mg/L. Untuk mengetahui jumlah zat padat terlarut pada sampel digunakan TDS meter. Dari hasil pengukuran TDS yang dilakukan dilaboratorium menunjukkan bahwa TDS pada keempat lokasi penelitian memenuhi syarat kualitas air bersih berturut-turut dari lokasi pertama sampai keempat adalah: 201, 138, 185, dan $185 \mathrm{mg} / \mathrm{L}$. TDS pada air yang diperbolehkan oleh Peraturan Menkes 2010 yaitu 500 mg/L. Jadi pada keempat lokasi penelitian dari segi TDS air PDAM memenuhi syarat kualitas air minum.

\section{Derajat Keasaman (pH)}

pH kualitas air PDAM yang diperbolehkan Peraturan Menkes 2010 Nomor 492 Tahun 2010 yaitu 6,58,5 . Hasil pengukuran $\mathrm{pH}$ yang dilakukan di laboratorium menunjukkan bahwa $\mathrm{pH}$ pada keempat lokasi penelitian memenuhi syarat untuk minum yaitu secara berturut-turut dari lokasi pertama sampai lokasi keempat adalah: $\mathrm{pH}=8 ; 8 ; 8,3 ; 8,2$. $\mathrm{pH}$ penting dalam penentuan kualitas air karena keasaman air pada umumnya disebabkan gas oksida yang larut dalam air terutama karbondioksida. Pengaruh yang menyangkut aspek kesehatan dari pada penyimpangan standar kualitas air minum dalam hal $\mathrm{pH}$ yang lebih kecil 6,5 dan lebih besar dari 9,2 dapat menyebabkan beberapa senyawa kimia berubah menjadi racun yang sangat mengganggu kesehatan.

\section{Kesadahan $\left(\mathrm{CaCO}_{3}\right)$}

Kesadahan merupakan jumlah kandungan mineral dalam air. Pada umumnya kesadahan disebabkan oleh adanya logam-logam atau kation-kation yang bervalensi dua seperti besi (Fe), mangan ( $\mathrm{Mn}$ ), kalsium (Ca) dan magnesium $(\mathrm{Mg})$, tetapi penyebab utama dari kesadahan adalah $\mathrm{Ca}$ dan Mg. Klasifikasi tingkat kesadahan yang umumnya menunjukkan reaksi lunak, sedangkan air dalam keadaan basa umumnya merupakan air sadah keras.

Kesadahan yang diperoleh pada keempat lokasi penelitian pertama sampai keempat berturutturut adalah: 98,$09 ; 90,82 ; 89,09$ dan $84,07 \mathrm{mg} / \mathrm{L}$. Berdasarkan hasil yan diperoleh dan mengacu kepada kesadahan yang diperbolehkan dalam air minum sesuai standar Peraturan Menteri Kesehatan Nomor 492 Tahun 2010 yaitu 500 mg/L. Jika dibandingkan kesadahan pada keempat lokasi penelitian dengan Peraturan Menteri Kesehatan, maka dapat dikatakan air PDAM Kotamadya Ambon pada keempat lokasi penelitian memenuhi standar baku air minum yang baik. Konsentrasi kalsium dalam air minum yang lebih rendah dari $75 \mathrm{mg} / \mathrm{L}$ dapat menyebabkan penyakit tulang rapuh, sedangkan konsentrasi yang lebih tinggi dari $200 \mathrm{mg} / \mathrm{L}$ dapat menyebabkan korosifitas pada pipapipa air. Dalam jumlah yang lebih kecil magnesium dibutuhkan oleh tubuh untuk pertumbuhan tulang, akan tetapi dalam jumlah yang lebih besar $150 \mathrm{mg} / \mathrm{L}$ dapat menyebabkan rasa mual.

\section{KESIMPULAN}

Analisis parameter fisika serta $\mathrm{pH}$ dan kesadahan pada sumber air PDAM Wainitu, air pada instalasi pengolahan air PDAM Wainitu dan air pada kran pelanggan PDAM Wainitu meliputi: bau, 
rasa, warna, suhu dan jumlah zat padat terlarut (TDS), serta pH dan kesadahan memenuhi syarat standar baku air minum berdasarkan Peraturan Menteri Kesehatan Nomor 492 Tahun 2010.

\section{DAFTAR PUSTAKA}

Efendi, 2003. Telah Kualitas Air bagi Pengelolaan Sumber Daya Air dan Lingkungan, Kanisius, Yogjakarta.

Gusril, H.,2016. Studi Kualitas Air Minum, Jurnal Geografi Vol 2: 190-196

Kementerian Kesehatan RI, 2010. Peraturan Menteri Kesehatan Republik Indonesia Nomor 492/Menkes/Per/IV/2010 Tentang Persyaratan Kualitas Air Minum.Jakarta.

Mulyono, H., 2009. Membuat Reagen Kimia di Laboratorium, Penerbit Bumi Aksara, Jakarta.

Sutrisno, 2006. Teknologi Penyediaan Air Bersih, Penerbit Rineka Cipta, Jakarta. 